\title{
MAPPING PROCESS IMPROVEMENT AND SEQUENCING ANALYSIS FOR PRODUCTIVE DEFINITIONS: A CASE STUDY IN A METALLURGICAL INDUSTRY
}

\author{
Giovane Oliveira Cardoso ${ }^{1}$ and Izamara Cristina Palheta Dias ${ }^{2}$
}

\author{
${ }^{1,2}$ University Center Andrade Campos - UNIANDRADE. Curitiba-Paraná. Brazil.
}

Email: giovane_olivera@hotmail.com, izamarai@hotmail.com

Received: Nov $20^{\text {th }}, 2019$

Accepted: Jan $23^{\text {th }}, 2020$

Published: February $10^{\text {th }}, 2020$

Copyright (C2016 by authors and Galileo Institute of Technology and Education of the Amazon (ITEGAM).

This work is licensed under the Creative Commons Attribution International License (CC BY 4.0).

https://creativecommons.org/licen ses/by/4.0/

\begin{abstract}
With a constant and complex change in the manufacturing market, it is essential that companies are always growing steadily and looking for internal improvements not to lose their place in the market. These improvements initiated by organizational management, to make the company more competitive in the market that is inserted. For this, everyone involved in the process must know exactly how the information flow, the sequencing of operations and the expected result at the end of them. Knowing this importance, the present study deals with a process mapping and analysis, where we observed the problems faced in a metallurgical industry located in Curitiba-PR, and based on a theoretical framework on this approach and how its application is made. Defining the company flowchart from the process mapping, as a result, several failures and opportunities for improvement were found, generating a new proposal of a process flowchart that has already been implemented and is having positive organizational results for the industry in question.
\end{abstract}

Keywords: Process mapping, Organizational Management, Metallurgical industry.

\section{INTRODUCTION}

Process is a set of activities/operations together with people, equipment, procedures and information flow, transforms an input (an input) in a product or service (output), according to customer needs. It is necessary for this product or service, add value and bring positive results for the company.

With the current market increasingly competitive, it is essential to good management and business administration at all for you to be ahead of your competitors to guarantee the standardization of internal processes is necessary because with this, the company can achieve greater efficiency with the reduction of costs, resulting in productivity gains and a more competitive price in the market, thus ensuring greater customer satisfaction.

Nowadays, with advances in technology and business management, we see how the market competitiveness has been growing in many areas, thus causing increasingly necessary, the company is in constant search for knowledge and marketing strategies for do not end up wasting your space for the other competitors.
For an essential business development that the company can identify their shortcomings in the production system in order to make the necessary improvements in its productive and organizational processes. A very effective remedy to observe these flaws is the process of mapping, which is to establish an organized manner the steps and sequencing of activities that sustain the company.

Disorganized company can generate low productivity, unmotivated employees, no information operations, which directly affects the quality of the product or service, and the loss of time and money for the company, so that there may be an increase of quality and that the production process is the best and fastest is necessary organization and sequencing of all processes.

This study deals with an analysis and modification of a mapping process for a company in the metal industry that suffers from problems caused by lack of standardization of its processes, in which there is no documentation that defines the exact sequence to be followed after each operation executed, as the company is a service provider in the machining industry, and its products end unique pieces and cannot therefore be held to standardize processes for each final product, so in order to facilitate the flow of 
information, will be conducted research and created a stream of general processes in order to improve the current situation of the company, and make the information flow more facilities between one operation and another, giving a better quality in service, in a shorter interval of time between the service request and the issuance of the final product, as now, no proper sequencing, the product ends up getting lost during a process and another, thus causing a delay of the application and consequently discontent and bad view of the customer to the company.

This article is structured as follows: Section 1 presents the introduction, in which there is exposure of the subject matter; Section 2 presents a literature review of research; Section 3 exposed the materials and methods used in the preparation of the article; In Section 4 we have the statement of conclusions and then are cited the references used.

\section{THEORETICAL}

\section{II.1 MANAGEMENT ORGANIZATION}

According to [1] organizational management is nothing more than the management of a business, company or organization in order to achieve goals and conquer positive and profitable results.

The function of this type of management philosophy is to lead people and processes effectively, encouraging improvements, create a collaborative environment, motivated, conducive to selfdevelopment and, consequently, the achievement of results.

The management concept aims to achieve the most satisfactory results possible. However, they are only achieved when the strategies and processes are in tune. The company builds its own set of principles and values that result from the interaction of people.

\section{II.2 PROCESS CONCEPT}

Process is related to everything that exists in life, considering that for everything there is a precedent stage, a processing step and a consequent step. They reach this conclusion based on the understanding that everything that makes up life is based on a succession of events, either in the relationship between the animals in natural phenomena, or behavior and human relationships, everything is constantly changing, ie, the observed object has a previous format, undergoes a modification step and molds with another format (be it physical format, behavioral, technological or material) [2].

To [3] process is a group of activities in a logical sequence in order to produce a good or a service that is of value to a specific group of customers.

The [4] addresses that process is a set of sequential activities that present logical link between them, in order to meet and preferably surpass the needs and expectations of internal and external customers of the company.

The [5] state that a process consists of a sequence executed set of tasks in order to generate an identifiable result, which can be a good, a service, data or information. The result of the process is always directed to a client, whether internal or external, that is who defines and evaluates this result.

We conclude then that process is a set of tasks performed in a logical sequence that has a goal of generating an identifiable outcome that meets the previous settings by the customer, whether internal or external, thus generating a value for a specific group of customers and adding value the company.

\section{II.2.1 PROCEDURES FOR ENTERPRISE SERVICES PROVIDER}

To [6] in the service companies, the concept of process is of fundamental importance, since the sequence of activities is not always visible, or by the client or by the people who perform these activities.

For personal service companies, processes are activities sequences that are necessary to carry out the transactions and provide the service [7].

The service sector is a very sensitive market segment the customer because it is intangible, the buying process is always well researched and studied by consumers. Being intangible, which is sold is a promise according to what was requested by the client (other than a tangible product that proves it before buying).

According to [8] in this business segment the weakness is in ensuring compliance with the agreed promises to customers and so the contractors investigating the company to be deeply engaged in order to check on other services already performed before delivery capacity than is being promised also consult reviews and opinions of those who have received the provision of the same services to make sure they are minimizing the margin of error at the time of purchase.

For the service provider company to fulfill its promise to the right customer, this should have consolidated two major assets: People and Processes.

People who carry out the agreed activities shall be satisfied, motivated, skilled and engaged and processes must be mapped, modeled, diagrammed, adjusted, tested and automated.

The combination of these two well-structured assets allow the company to fulfill its role and deliver what has been agreed, exceeding customer expectations, making money from it (cashing) and continuously improving its image in the market competition.

Therefore, in the case of services, customer satisfaction goes through human interaction (people) that is directly linked to quality of service provided by the company.

Thus, it is essential that the company has a staff of skilled employees, trained, motivated and prepared for such service, and that communication client/company is very well defined, taking into account that the issue listen to the customer is an important step the service.

\section{II.3 PROCESS MAPPING}

To [9] process mapping is a management and communication tool intended to help improve existing processes or implement a new structure facing processes. Their analysis allows to reduce costs in product development and services, reducing integration gaps between systems and improves the performance of the organization as well as being an excellent tool to enable better understanding of the current processes and eliminate or simplify those require changes.

Map helps identify sources of waste, providing a common language to address the manufacturing processes and services, making decisions on visible flow so they can discuss them, adding concepts and lean techniques, which help to avoid implementing some isolation techniques forming the basis for an implementation plan and showing the relationship between the flow and the flow of information materials [10].

\section{II.3.1 MAPPING CURRENT PROCESS (AS IS)}

The first step to be taken when doing a project is to understand the existing process and identify their weaknesses so 
that the present situation (As Is) process is thoroughly documented in order to have a common definition and shared the process [11].

The effect of mapping the current state, is expected to achieve [12].

- The model of the process currently in use;

- Metrics appropriate and sufficient to establish a basis for future measures to improve processes;

- Metrics and the current process performance documentation;

- Documentation of what is working well and what needs improvement.

- Identification of the most significant and rapid return items, which can be easily implemented;

- Not return to mistakes of the past.

\section{II.3.2 PROCESS MAPPING THE FUTURE (TO BE)}

According to [11] to model the future state should create a space for discussion and exchange of information between those involved in order to improve processes, Inova them and question whether it is necessary and actually adds value required the company. It is expected the modeling of the future state, the following steps.

- Process redesign or realization of a new process;

- Documentation of modifications or creation process;

- Simulation models;

- Confirming expectations of those involved regarding the changes;

- Confirmation alignment with the strategy;

\section{II.3.3 FLOW CHART}

The [2] define as flowchart a picture made with standard symbols and texts properly arranged to show logical sequence of conducting process steps or activities. Still they say that the graphic display is always a powerful communication channel, to be better absorbed and better understanding of the written texts, which require mental effort and are more subjective.

For [13] The flowchart is described as an imaging technique, in which use is made of previously agreed symbols, allowing clear and precise description of the flow of a process or sequence, as well as their interpretation and drawing.

\section{II.3.3 USE OF BENEFITS FLOW CHART}

According to [2] flowcharts insert is enriching for the working environment, because it facilitates the interpretation joint and contributes to the display of the workflow process documented. Therefore, the flowchart of use provides the following benefits: Process overview, critical details of the process visualization, process flow identification and interactions between sub-processes, identify potential control points (indicators) and identification of inconsistencies and weaknesses.
The [14] points out the following advantages regarding the flowchart: check how the components of a system; It proposes a simpler understanding and objective; facilitates the location of the deficiencies; It can be applied to any system, from the simplest to the most complex and enables rapid understanding that any changes to existing systems is proposed.

\section{II.3.4 THE IMPORTANCE OF FLOW CHART}

The [14] identifies the flow charts are important for the improvement of business processes in order to understand the inner workings and relationships between them. The flowchart then allows, through the documentation of processes, identify bottlenecks and points for improvement, areas that need to be improved.

To [15] the flowchart is important to determine the starting point; to gather, select and elect the problems priorities; to identify which activities are possible simplification and power to extinguish activities that are not being more useful and inefficiency end up bringing the proceedings. Next to that, the use of it allows us to identify the operation of any operation, regardless of its degree of complexity, allowing understanding through visual representation of how the process is run, since it maps the processes and explicit the inputs and outputs of all sub-processes.

\section{MATERIALS AND METHODS}

\section{III.1 CLASSIFICATION OF RESEARCH}

The study in question is classified as exploratory research, as suggested by the name, the exploratory research seeks to explore a problem or a situation to provide criteria and understanding. According to [16] it is simply used to find the cause of a problem. Exploratory research uses methods very spacious and versatile. The methods used include: surveys on secondary sources (bibliographical, documentary, etc.), experience surveys, selected case studies and informal observation (to the naked eye or mechanical).

\section{III.2 COMPANY DESCRIPTION STUDY}

This study was conducted in a metalworking company located in Curitiba- PR.

The company has mainly focused on general machining, and a service provider that provides unique pieces not so can the standardization of items produced will cease after the purchase order of its customers, therefore, has no stock of raw materials, which is only purchased to meet the application requested.

To develop the study, was analyzed as was the business process flow from the customer's purchase order to the final part of the delivery of the finished material, after this analysis was created flowchart processes of the present situation in which the company and later found to this it was an analysis of all stages and where was the opportunities for improvement. 
III.3 FLOW CHART OF THE COMPANY BEFORE THE STUDY

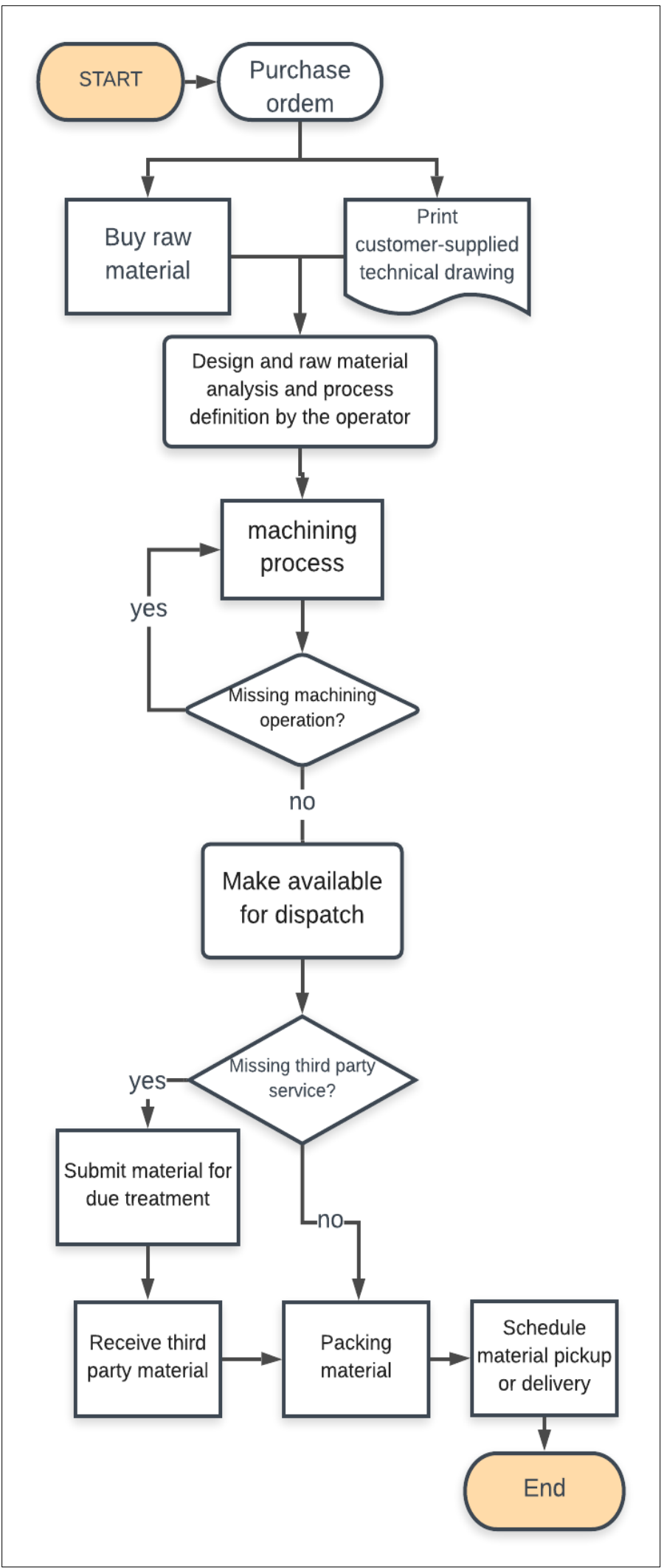

Figure 1: Flow chart of the company at an early stage. Source: Authors, (2019).
III.4 CURRENT FLOW CHART AFTER ANALYSIS OF FAILURES

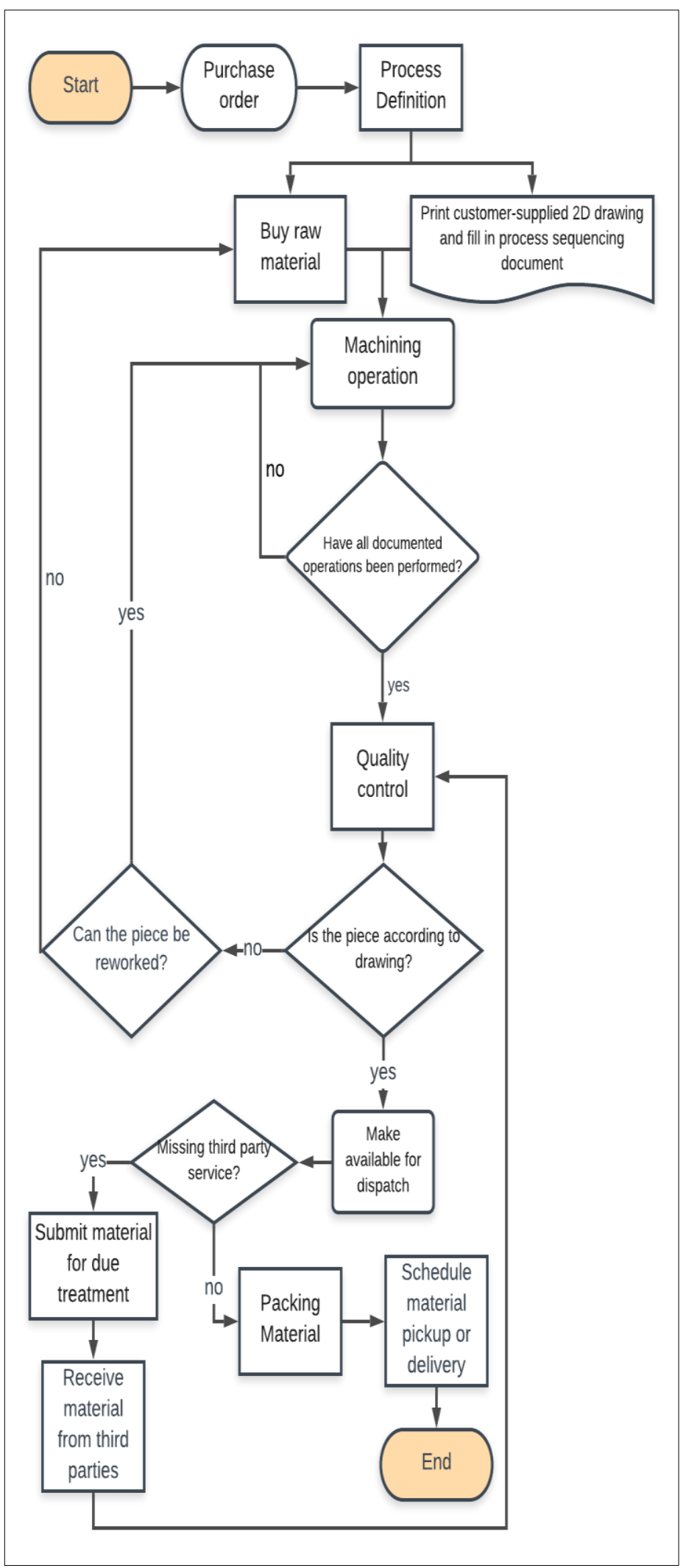

Figure 2: Current Flow chart of the company. Source: Authors, (2019). 


\section{III.5 IMPACTS CAUSED B Y CHANGES}

Overall, the major improvements made were as follows:

- Every drawing sent by the customer, being attached to your back, a firm internal document where it is shown the period of delivery, the order number of production and operations to be performed for the part in question, where the operator registers its name and the time taken for such service.

- Problem: Before applying this method, the company suffered daily with the lack of a definition of what operations would be carried out as a single piece, can be reality in several different machines, thereby causing a mess in the process and even the incorrect fabrication material.

-With the date set by the customer clearer to operators, is more visible for them to know and define which parts have to be prioritized, and even set a deadline to end its operation.

-Problem: Previously, operators had no clear sequence of what parts would be machined in the day, so after finishing each task, was lost time to the definition of the next material to be machined

- With the document marking all necessary operations, reduces the risk of the piece to be released to the quality lacking some type of operation and have to return again to the factory.

- Problem: As before the implementation of this document there was still no quality control, some of the time, responsible for shipping any non-compliance found in the material, thus making the piece back to the factory, thus compromising the day of planning and preparing machine.

- With a person responsible for quality control, many errors are found before the part is delivered to the customer, was also deployed a measurement report, where $100 \%$ of the dimensions specified in the drawing are controlled in that report and sent together with the material to the customer, through greater assurance that the material is supplied according to their needs.

- Problem: Before the company count on quality control, the quality of the materials supplied were guaranteed only by the measurement of machine operators, and due to lack of time, correct tools and measuring availability, often the material was not supplied according to the specifications, generating complaints from some customers return the material after delivery, and a bad view of customers about the company.

- Any material that is carried to third parties for surface treatment, heat treatment, welding, grinders, among others, have to return to the company, and be analyzed by the quality and the dimensional also be completed report.

- Problem: It has been observed that sometimes, the stuff went straight to third parties for the client without any quality control and even look, and when he returned to the company, it was just packed with no verification.

Above was introduced some improvements made possible by the visualization of the flow chart that was the company in the initial stage, it is noteworthy that with the view clearer process to all involved, it becomes easier to see new opportunities for improvement, as the process of mapping assists in the continuous process improvement and may thus arise new idea and fixes the right time.

\section{CONCLUSIONS}

In this study, we made a literature review on the mapping topic and improvement process in which after research and studies on this subject, created the flow chart in which the company was, therefore, be found numerous shortcomings and opportunities for improvement in the process, thus demonstrating the importance of a process flow well defined and as the organizational management is the basis for a company that seeks growth and competitiveness in the labor market. The presented improvements were qualitative fist, as each change made after the creation of the flowchart served as an improvement in the quality of the work environment, the quality of the supplied product and the best service in relation to the deadlines set by customers considering an improvement in the flow information and sequencing process. Note that the flowchart shown in this article, was not used in the company for analysis and process improvement, as the present study focused on demonstrating the importance of a business organization and how to create a flowchart can help companies to find gaps and opportunities for improvement, thus the flow diagram is a simplification, since the focus of the work is not complete description of operations and details that would flee the main subject matter.

\section{REFERENCES}

[1] Marques, Jose. Gestão organizacional: conceito e definições. Disponível em:<https://www.ibccoaching.com.br/portal/rhgestao-pessoas/gestao-organizacional-conceito-definicao.Acesso em: 04 nov. 2019.

[2] Maranhão, M.; Macieira, B. E. M. O processo nosso de cada dia, modelagem de processos de trabalho. Rio de Janeiro: Qualitymark, 2010.

[3] Hammer, Michael; Champy, James. Reengineering the corporation. New York: HarperBusiness, 1994.

[4] Oliveira, Djalma de Pinho R. Revitalizando a empresa: a nova estratégia de reengenharia para resultados e competitividade: conceitos, metodologia, práticas. São Paulo: Atlas, 1996.

[5] Adair, C. B.; Murray, B. A. Revolução total dos processos. São Paulo: Nobel, 1996.

[6] Gonçalves, José Ernesto Lima. As empresas são grandes coleções de processo. RAE Revista de Administração de Empresas, v. 40, n. 1, p. 6-19, jan./mar. 2000.

[7] Ramaswamy, Rohit. Design and management of service processes. Reading: Addison Wesley, 1996.

[8] Regis, Fernando. A importância dos processos para as empresas de serviços. Disponível em: $<$ https://administradores.com.br/artigos/a-importancia-dosprocessos-para-as-empresas-de-servicos $>$. Acesso em: 26 mai. 2019.

[9] Hunt, V. D. (1996) - Process Mapping: How to Reengineer your Business Process. John Wiley \& Sons, New York

[10] Corrêa, Karlos E. S; Gonçalves, Rafael; Lima, Renato da S; Almeida, Dagoberto A. de. Mapeamento do Processo de Fornecimento em uma Rede de Supermercados. XXV ENEGEP Encontro Nacional de Engenharia de Produção, Porto Alegre, RS Nov 2005.

[11] Baldam, Roquemar et al. 2008. Gerenciamento de Processos de Negócios. São Paulo: Ética, 2008. 
[12] Jeston, J.; Nelis, J. Business Process Management: pratical guidelines to successful impementations. Oxford: Elsevier, 2006.

[13] D'ascenção, Luiz Carlos M. Organização, Sistemas e Métodos. Análise, redesenho e informatização de processos administrativos. São Paulo: Atlas, 2001.

[14] Cury, A. Organização e métodos: Uma visão holística. São Paulo: Atlas, 2015.

[15] Kamel, N. M. Melhoria e reengenharia de processos empresariais focando o cliente. São Paulo: Erica, 1994. ISBN 857194203X.

[16] Boone, C. E.; Kurtz, D. L. Marketing contemporâneo. 8. ed. Rio de Janeiro: LTC, 1998. 